\title{
Assessment of causality and severity of various reported adverse drug reactions by different classes of anti-cancer drugs
}

\author{
Shaheena Rasool ${ }^{1}$, Masarat Nazeer ${ }^{1}$, Mehwish Majeed ${ }^{2 *}$
}

${ }^{1}$ Department of Pharmacology,
Government Medical College,
Srinagar, Jammu and Kashmir,
India
${ }^{2}$ Department of Pharmacology,
SKIMS, Soura, Srinagar, India

Received: 23 December 2017

Revised: 04 January 2018

Accepted: 29 January 2018

\section{*Correspondence to:}

Dr. Mehwish Majeed,

Email: mehwishmajeed10@ gmail.com

Copyright: (C) the author(s), publisher and licensee Medip Academy. This is an openaccess article distributed under the terms of the Creative Commons Attribution NonCommercial License, which permits unrestricted noncommercial use, distribution, and reproduction in any medium, provided the original work is properly cited.

\begin{abstract}
Background: Chemotherapy involves highly complex regimens and hence accounts to high susceptibility towards Adverse Drug Reactions. All antineoplastic drugs have potential to cause one or more Adverse Drug Reactions which may vary from mild to severe form. So the aim of this study was to determine the prevalence of Adverse Drug Reactions in patients treated with chemotherapy.

Methods: After getting approval from the Institutional Ethical Committee, the prospective observational study was conducted in the Department of Pharmacology in association with Department of Radiation Oncology and Department of Medicine, Government Medical College, Srinagar between April 2015 to October 2016. All patients of either sex and any age receiving anti-cancer drugs in the inpatient department of radiation oncology were included. The mean age of the study population was 51 years and $53.9 \%$ of them were males and $46.1 \%$ of them were females. The WHO-UMC system was used for assessment of case programme and case reports. The severity of adverse drug reactions was determined by using modified Hart wig and Siegel scale.

Results: Most of the reported ADR's were moderate to mild in severity according to modified Hart wig and Siegel scale. Most of the frequent ADR's were certain followed by probable and possible according to WHO-UMC causality assessment.

Conclusions: Antineoplastic drugs have a narrow therapeutic index and the dosage needed to achieve a therapeutic response usually proves toxic to the body's rapidly proliferating cells. Measures need to be put into place to reduce the physical, emotional and economic burden on the patient due to adverse drug reactions. Therefore, there is a need for vigilant ADR monitoring to decrease morbidity and mortality due to ADR's which require further studies on large populations.
\end{abstract}

Keywords: Anti-cancer drugs, Chemotherapy, Hart wig and Siegel scale, WHOUMC system

\section{INTRODUCTION}

ADRs are considered among the leading causes of morbidity and mortality causing hospital visits and admissions. In relation to mortality a landmark metaanalysis of 39 prospective studies found that ADRs resulting in medical care were the fourth to sixth highest cause of death in emergency services in United States, following only ischemic cardiopathy, cancer and stroke. ${ }^{1,2}$
Many reports have shown that there is an increase in the number of cancer cases in India every year. This increment in the incidence of cancer in India may be attributed to poor living standards, and due to inadequate medical facilities. $^{3,4}$ Chemotherapy is employed as part of a multimodal approach to the treatment of many tumors. ${ }^{5}$ Chemotherapy regimens are immensely complex, and cancer patients are a susceptible population with little tolerance. ${ }^{6}$ The magnitude of adverse drug reactions (ADR's) endured by oncology patients is colossal making 
them almost synonymous with the treatment. ${ }^{7}$ An adverse drug reaction (ADR) is a response to a drug that is noxious and unintended and occurs at doses normally used in humans for the prophylaxis, diagnosis and treatment of disease or for modification of physiological function. ${ }^{8}$ Adverse drug reactions are considered among the leading causes of morbidity and mortality causing hospital visits and admissions. Chemotherapeutic drugs have a narrow therapeutic index and the dosage needed to achieve a therapeutic response usually proves toxic to the body's rapidly proliferating cells. The normal tissues adversely affected by these drugs are those which are rapidly dividing: the bone marrow, gastrointestinal tract and hair follicles.

\section{METHODS}

After getting approval from the Institutional Ethical Committee, the prospective observational study was conducted in the Department of Pharmacology in association with Department of Radiation Oncology and Department of Medicine, Government Medical College, Srinagar and associated SMHS Hospital, between April 2015 to October 2016.

\section{Inclusion criteria}

All the patients of either sex and any age receiving anticancer drugs in the inpatient department of radiation oncology were included.

\section{Exclusion criteria}

Patients who did not give consent to participate in the study.

\section{WHO-UMC Scale}

The WHO-UMC system has been developed in consultation with National Centers participating in the programme for international Drug Monitoring and is meant as a practical tool for assessment of case programme for international Drug Monitoring, also for assessment of case reports. It is basically a combined assessment taking into account the clinico-pharmacological aspects of the case history and the quality of the documentation of the observation. This method gives guidance to the general arguments which should be used to select one category over another.

\section{Severity of adverse drug reactions}

The severity of adverse drug reactions was determined by using modified Hart wig and Siegel scale as given below: ${ }^{9}$

\section{Mild}

Adverse drug reactions which are self limiting and able to resolve over time without treatment and did not contribute to prolongation of length of stay

\section{Table 1: Classification of ADRs as per WHO-UMC Scale.}

\begin{tabular}{|ll|}
\hline Term & Description \\
& Event or laboratory test abnormality, with plausible time relationship to drug intake \\
Cannot be explained by disease or other drugs. & Response to withdrawal plausible (pharmacolo-gically, pathologically) \\
Event definitive pharmacologically or phenomeno-logical (i.e. an objective and specific \\
medical disorder or a recognized pharmacological phenomenon). \\
Rechallenge satisfactory, if necessary
\end{tabular}




\section{Moderate}

Adverse drug reactions are defined as those that required therapeutic intervention and hospitalization prolonged by 1 day but resolved in $<24 \mathrm{hrs}$ or change in drug therapy or specific treatment to prevent a further outcome.

\section{Severe}

Adverse drug reactions are those that were life threatening, producing disability and those that prolonged hospital stay or led to hospitalization or required intensive medical care.

\section{Lethal}

Adverse drug reactions are those that directly or indirectly contributed to patient's death.

Patient outcomes were reported as:

- Fatal

- Fully recovered (Patient fully recovered during hospitalization)

- Recovering (patient recovering, but not fully recovered during hospitalization)

- Unknown (not documented after initial report in chart)

\section{Statistical methods}

Data was entered in Microsoft Excel spread sheet. Data was summarized in the form of tables and graphs. Categorical variables were summarized as frequency and percentage.

\section{RESULTS}

Table 2 revels that most of the patients were in the age group of 50-60 years $(30.1 \%)$ followed by age group of 40 50 years $(27 \%)$. There were $76(53.9 \%)$ males and 65 $(46.1 \%)$ females in this study population.

Table 2: Distribution of the study population according to age and sex.

\begin{tabular}{|lllll|}
\hline $\begin{array}{l}\text { Age } \\
\text { (years) }\end{array}$ & Frequency & $\begin{array}{l}\text { Sex } \\
\text { Male }\end{array}$ & Female & Percent \\
\hline$\leq 10$ & 1 & 1 & 0 & 0.7 \\
\hline $11-20$ & 1 & 0 & 1 & 0.7 \\
\hline $21-30$ & 3 & 1 & 2 & 2.1 \\
\hline $31-40$ & 23 & 8 & 15 & 16.3 \\
\hline $41-50$ & 38 & 16 & 22 & 27.0 \\
\hline $51-60$ & 43 & 28 & 15 & 30.1 \\
\hline $61-70$ & 27 & 17 & 10 & 19.1 \\
\hline $71-80$ & 5 & 5 & 0 & 3.5 \\
\hline Total & 141 & 76 & 65 & 100 \\
\hline
\end{tabular}

Table 3 revels by occupation, most of the patients were belonging to two groups, i.e. Housewives $(44.7 \%)$ and farmers $(17.5 \%)$ and out of 141 enrolled patients, one patient was a toddler of $1 \frac{1 / 2}{2}$ year age.

Table 3: Distribution of study population according to occupation.

\begin{tabular}{|lll|}
\hline Occupation & Frequency & Percent \\
\hline Housewife & 63 & 44.7 \\
\hline Farmer & 25 & 17.5 \\
\hline Business man & 19 & 13.5 \\
\hline Ex-govt. employee & 12 & 8.5 \\
\hline Labourer & 6 & 4.3 \\
\hline Carpenter & 4 & 2.8 \\
\hline Pvt. Job & 3 & 2.1 \\
\hline Govt. Employee & 3 & 2.1 \\
\hline Student & 2 & 1.4 \\
\hline Tailor & 1 & 0.7 \\
\hline Driver & 1 & 0.7 \\
\hline Blacksmith & 1 & 0.7 \\
\hline Total & 140 & 100 \\
\hline
\end{tabular}

Table 4 indicates that Carcinoma colon $19.9 \%$ was the most common malignancy in the study population followed by carcinoma breast $16.3 \%$, stomach $15.6 \%$, lung $9.2 \%$, ovary and rectum $6.4 \%$.

Table 4: Distribution of study population according to cancer type.

\begin{tabular}{|ll|l|}
\hline Diagnosis & Frequency & Percent \\
\hline CA Colon & 28 & 19.9 \\
\hline CA Breast & 23 & 16.3 \\
\hline CA Stomach & 22 & 15.6 \\
\hline CA Lung & 13 & 9.2 \\
\hline CA Ovary & 9 & 6.4 \\
\hline CA Rectum & 9 & 6.4 \\
\hline GE junction Growth & 7 & 5.0 \\
\hline CA Pancreas & 5 & 3.5 \\
\hline NHL & 4 & 2.8 \\
\hline CA Gall bladder & 3 & 2.1 \\
\hline CA Larynx & 3 & 2.1 \\
\hline CA Esophagus & 3 & 2.1 \\
\hline RCC & 2 & 1.4 \\
\hline CA Testis & 2 & 1.4 \\
\hline Retinoblastoma & 1 & 0.7 \\
\hline CUPS & 1 & 0.7 \\
\hline CA Ethmoid sinus & 1 & 0.7 \\
\hline Rhabdomyosarcoma (hand) & 1 & 0.7 \\
\hline Periampullary CA & 1 & 0.7 \\
\hline CA Rectumandovary & 1 & 0.7 \\
\hline CA Thyroid & 1 & 0.7 \\
\hline CA Urinary Blader & 1 & 0.7 \\
\hline Total & 141 & 100 \\
\hline NHL = Non-Hodgkin's lymphoma; RCC $=$ Renal cell carcinoma; \\
CUPS = Carcinoma of unknown primary site \\
\hline
\end{tabular}


Table 5: Anticancer drugs used in study population.

\begin{tabular}{|c|c|c|}
\hline Name of the regimen/ drug & Frequency & Percent \\
\hline Folfox (5-FU, Oxaliplatin) & 27 & 19.14 \\
\hline $\begin{array}{l}\text { ECF (Epirubicin, cisplatin, 5- } \\
\text { FU) }\end{array}$ & 24 & 17.02 \\
\hline Paclitaxel+Carboplatin & 11 & 7.80 \\
\hline Folfiri (5-FU, Irinotican) & 7 & 4.96 \\
\hline Paclitaxel+cisplatin & 5 & 3.5 \\
\hline Gemcitabine+cisplatin & 5 & 3.5 \\
\hline Cisplatin+5-FU & 5 & 3.5 \\
\hline Cisplatin+Etoposide & 5 & 2.8 \\
\hline $\begin{array}{l}\text { RCHOP (Rituximab, } \\
\text { cyclophosphamide, doxorubicin, } \\
\text { oncovin, prednisolone) }\end{array}$ & 4 & 2.8 \\
\hline Docetaxel+capecitabine & 4 & 2.8 \\
\hline Paclitaxel+Gemcitabine & 4 & 2.8 \\
\hline Oxaliplatin+capecitabine & 4 & 2.8 \\
\hline Docetaxel+Irinotican & 3 & 2.1 \\
\hline Adriamicim+Cyclophosphamide & 3 & 2.1 \\
\hline Gemcitabine+Oxaliplatin & 3 & 2.1 \\
\hline Docetaxil+Carboplatin & 2 & 1.4 \\
\hline Sunitinib & 2 & 1.4 \\
\hline Paclitaxel & 2 & 1.4 \\
\hline Docetaxel+cisplatin & 1 & 0.7 \\
\hline Gemcitabine+Capecitabine & 1 & 0.7 \\
\hline Adriamycin+Ifosphamide & 1 & 0.7 \\
\hline $\begin{array}{l}\text { Formorubicin+Cyclophosphami } \\
\text { de }\end{array}$ & 1 & 0.7 \\
\hline $\begin{array}{l}\text { Oxaliplatin+Bevacuzumab+cape } \\
\text { citabine }\end{array}$ & 1 & 0.7 \\
\hline CAF (cisplatin, Apristar, 5-FU) & 1 & 0.7 \\
\hline $\begin{array}{l}\text { Paclitaxel+cisplatin+Ifosphamid } \\
\text { e }\end{array}$ & 1 & 0.7 \\
\hline $\begin{array}{l}\text { BEP (Bleomycin, Etoposide, } \\
\text { cisplatine) }\end{array}$ & 1 & 0.7 \\
\hline Pemetrexed+Carboplatin & 1 & 0.7 \\
\hline Pemetrexed+cisplatin & 1 & 0.7 \\
\hline $\begin{array}{l}\text { Docetaxel+Doxorubicin+Cyclop } \\
\text { hosphamide }\end{array}$ & 1 & 0.7 \\
\hline $\begin{array}{l}\text { EC (Epirubicin, } \\
\text { Cyclophosphamide) }\end{array}$ & 1 & 0.7 \\
\hline Docetaxel+Cyclophosphamide & 1 & 0.7 \\
\hline Bevacuzumab+Capecitabine & 1 & 0.7 \\
\hline Cisplatin+Capecitabine & 1 & 0.7 \\
\hline Trastuzumab & 1 & 0.7 \\
\hline $\begin{array}{l}\text { Adriamycin+Paclitaxel+Trastuz } \\
\text { umab }\end{array}$ & 1 & 0.7 \\
\hline $\begin{array}{l}\text { DCF (doxorubicin, cisplatin, 5- } \\
\text { FU) }\end{array}$ & 1 & 0.7 \\
\hline $\begin{array}{l}\text { Vincristine+Carboplatin+Etopos } \\
\text { ide }\end{array}$ & 1 & 0.7 \\
\hline Irinotican & 1 & 0.7 \\
\hline Gemcitabine & 1 & 0.7 \\
\hline Total & 141 & 100 \\
\hline
\end{tabular}

Table 5 reveals that common regimens used in the study population were those of Folfox (19.14\%), ECF (17.02\%), Paclitaxel + Carboplatin (7.80\%) and Folfiri (4.96\%).

Table 6 shows that all enrolled (141) patients in the study population developed adverse drug reactions.

Table 6: Distribution of study population according to adverse drug reaction.

\begin{tabular}{|lll|}
\hline ADR & Frequency & Percent \\
\hline Present & 141 & 100 \\
\hline Total & 141 & 100 \\
\hline
\end{tabular}

Table 7 shows that gastrointestinal tract was the most common organ system involved by adverse drug reactions.

Table 7: Frequency of ADRs according to organ system involved.

\begin{tabular}{|c|c|c|}
\hline System Involved & $\begin{array}{l}\text { Number of } \\
\text { ADR's }\end{array}$ & Percentage \\
\hline Gastrointestinal & 311 & 37.02 \\
\hline $\begin{array}{l}\text { Musculoskeletal and } \\
\text { connective tissue }\end{array}$ & 181 & 21.54 \\
\hline Haematological & 138 & 16.42 \\
\hline $\begin{array}{l}\text { Skin and Sub- } \\
\text { cutaneous tissue }\end{array}$ & 109 & 12.97 \\
\hline Neurological & 56 & 6.66 \\
\hline Infections & 26 & 3.09 \\
\hline Others & 12 & 1.42 \\
\hline Electrolyte imbalance & 6 & 0.71 \\
\hline Renal & 1 & 0.11 \\
\hline Total & 840 & 100 \\
\hline
\end{tabular}

Table 8 shows that as per the WHO-UMC scale for assessing causality of ADRs, among 840 adverse drug reactions, $39.28 \%$ were classified as certain, $34.04 \%$ were probable and $25.35 \%$ were possible.

Table 8: Causality assessment according to WHOUMC Scale.

\begin{tabular}{|ll|l|}
\hline WHO-UMC scale category & Frequency & Percent \\
\hline Certain & 330 & 39.28 \\
\hline Probable & 286 & 34.04 \\
\hline Possible & 213 & 25.35 \\
\hline Unlikely & 11 & 1.3 \\
\hline Total & 840 & 100 \\
\hline
\end{tabular}

Table 9 shows that ECF regimen accounted for $19.79 \%$ of adverse drug reactions followed by Folfox $18.69 \%$ and Paclitaxel + Carboplatin 8.09\%.

Table 10 shows that most of the adverse drug reactions in the study population were in the age group of 40-50 years $(29.76 \%)$ followed by $50-60$ years $(28.92 \%)$. 
Table 9: ADR status in patients according to regimens/drug used.

\begin{tabular}{|c|c|c|}
\hline Regimen/drug & $\begin{array}{l}\text { No. of } \\
\text { ADR's }\end{array}$ & Percent \\
\hline $\mathrm{ECF}$ & 166 & 19.79 \\
\hline Folfox & 157 & 18.69 \\
\hline Paclitaxel + carboplatin & 68 & 8.09 \\
\hline FOLFIRI & 45 & 5.35 \\
\hline Paclitaxel + cisplatin & 35 & 4.16 \\
\hline Cisplatin + 5-FU & 30 & 3.57 \\
\hline Gemcitabine + cisplatin & 27 & 3.21 \\
\hline Cisplatin + etoposide & 27 & 3.12 \\
\hline Oxaliplatin + capecitabine & 23 & 2.73 \\
\hline Paclitaxel + gemcitabine & 23 & 2.73 \\
\hline Docetaxel + capecitabine & 19 & 2.26 \\
\hline R-CHOP & 18 & 2.14 \\
\hline Docetaxel + irinotican & 18 & 2.14 \\
\hline Gemcitabine + oxaliplatin & 16 & 1.90 \\
\hline Adriamycin + cyclophosphamide & 13 & 1.54 \\
\hline Paclitaxel & 12 & 1.42 \\
\hline Docetaxel + carboplatin & 11 & 1.30 \\
\hline Pemetrexed + carboplatin & 10 & 1.19 \\
\hline $\mathrm{BEP}$ & 10 & 1.19 \\
\hline Gemcitabine + capecitabine & 8 & 0.95 \\
\hline $\mathrm{CAF}$ & 8 & 0.95 \\
\hline $\begin{array}{l}\text { Oxaliplatin + bevacizumab + } \\
\text { capecitabine }\end{array}$ & 8 & 0.95 \\
\hline Sunitinib & 8 & 0.95 \\
\hline Adriamycin + ifosfamide & 7 & 0.83 \\
\hline Pemetrexed + cisplatin & 6 & 0.71 \\
\hline Bevacizumab + capecitabine & 6 & 0.71 \\
\hline Paclitaxel + cisplatin + ifosfamide & 6 & 0.71 \\
\hline Gemcitabine & 6 & 0.71 \\
\hline Docetaxel+ cisplatin & 5 & 0.59 \\
\hline Cisplatin+ capecitabine & 5 & 0.59 \\
\hline Trastuzumab & 5 & 0.59 \\
\hline $\begin{array}{l}\text { Adriamycin + paclitaxel + } \\
\text { trastuzumab }\end{array}$ & 5 & 0.59 \\
\hline Irinotican & 5 & 0.59 \\
\hline Docetaxel+ cyclophosphamide & 4 & 0.47 \\
\hline Formorubicin+ cyclophosphsmide & 4 & 0.47 \\
\hline $\mathrm{EC}$ & 4 & 0.47 \\
\hline $\begin{array}{l}\text { Vincristine + etoposide + } \\
\text { carboplatin }\end{array}$ & 4 & 0.47 \\
\hline $\begin{array}{l}\text { Docetaxel }+ \text { doxorubicin }+ \\
\text { cyclophosphamide }\end{array}$ & 4 & 0.47 \\
\hline $\mathrm{DCF}$ & 4 & 0.47 \\
\hline Total & 840 & 100 \\
\hline
\end{tabular}

Table 11 shows that Adverse drug reactions were more common in males $(50.95 \%)$ as compared to female $(49.04 \%)$. Table 12 shows that $52.6 \%$ of the adverse drug reactions were moderate in severity, $45.2 \%$ were mild and $2.14 \%$ were severe.
Table 10: Distribution of study population according to age and ADR.

\begin{tabular}{|lll|}
\hline Age (years) & No. of ADR's & Percent \\
\hline$\leq 10$ & 4 & 0.47 \\
\hline $11-20$ & 5 & 0.59 \\
\hline $21-30$ & 24 & 2.85 \\
\hline $31-40$ & 138 & 16.42 \\
\hline $41-50$ & 250 & 29.76 \\
\hline $51-60$ & 243 & 28.92 \\
\hline $61-70$ & 156 & 18.57 \\
\hline $71-80$ & 20 & 2.38 \\
\hline Total & 840 & 100 \\
\hline
\end{tabular}

Table 11: Distribution of study population according to sex and ADR.

\begin{tabular}{|lll|}
\hline Sex & No. of ADR's & Percent \\
\hline Male & 428 & 50.95 \\
\hline Female & 412 & 49.04 \\
\hline Total & 840 & 100 \\
\hline
\end{tabular}

Table 12: Severity of ADR in the study population according to Hartwig and Siegel scale.

\begin{tabular}{|lll|}
\hline Severity of ADR & Frequency & Percent \\
\hline Mild & 380 & 45.2 \\
\hline Moderate & 442 & 52.6 \\
\hline Severe & 18 & 2.14 \\
\hline Total & 840 & 100 \\
\hline
\end{tabular}

Table 13 shows that Platinum group of drugs (Cisplatin, Carboplatin, Oxaliplatin) were responsible for most of the Adverse drug reactions followed by 5-FU and Taxanes (Paclitaxel and Docetaxel). ECF regimen caused $27.79 \%$ severe adverse drug reactions followed by 5-FU + cisplatin.

A total number of 141 patients were enrolled and followed during this period that were treated for different malignancies with different chemotherapeutic agents. Out of a total of 141 patients, there were $76(53.9 \%)$ males and $65(46.1 \%)$ females. In this study, most of the patients i.e. $43(30.1 \%)$ were in the age group of 50-60 years. The maximum number of females were in the age group of 4050 years while as the highest number of males were in the age group of 50-60 years.

Most of the patients were belonging to two groups, i.e. Housewives (44.7\%) and farmers (17.5\%) and out of 141 enrolled patients, one patient was a toddler of $1 \frac{1}{2}$ year age. Most common malignancy in this study was colon (19.1\%), breast $(16.3 \%)$ and stomach (15.6\%). The common used antineoplastic drug regimens for the treatment of different malignancies were Folfox (19.4\%), ECF (17.02\%), Paclitaxel/ Carboplatin (7.80\%), Folfiri (4.96\%), Paclitaxel/ Cisplatin (3.5\%), Gemcitabine/ Cisplatin (3.5\%) and R-CHOOP (2.8\%). The overall 
prevalence of ADRs in this study was $100 \%$ i.e. all 141 enrolled patients developed one or more ADRs during the follow up.

Gastrointestinal tract was the most common organ system involved by adverse drug reactions. As per the WHOUMC scale for assessing causality of ADRs, among 840 adverse drug reactions, $39.28 \%$ were classified as certain, $34.04 \%$ were probable and $25.35 \%$ were possible. ECF regimen accounted for $19.79 \%$ of adverse drug reactions followed by Folfox $18.69 \%$ and Paclitaxel + Carboplatin $8.09 \%$.

Table 13: Severity of ADR'S according to regimens/ drug used.

\begin{tabular}{|c|c|c|c|c|}
\hline Regimen/drug & Mild & Moderate & Severe & No. of ADR's \\
\hline ECF & 71 & 90 & 5 & 166 \\
\hline FOLFOX & 70 & 87 & 0 & 157 \\
\hline Paclitaxel + carboplatin & 31 & 36 & 1 & 68 \\
\hline FOLFIRI & 18 & 26 & 1 & 45 \\
\hline Paclitaxel + cisplatin & 17 & 18 & 0 & 35 \\
\hline Cisplatin + 5-FU & 12 & 15 & 3 & 30 \\
\hline Gemcitabine + cisplatin & 11 & 15 & 1 & 27 \\
\hline Cisplatin + Etoposide & 13 & 14 & 0 & 27 \\
\hline Oxaliplatin + capecitabine & 11 & 12 & 0 & 23 \\
\hline Paclitaxel + gemcitabine & 13 & 10 & 0 & 23 \\
\hline Docetaxel + capecitabine & 5 & 13 & 1 & 19 \\
\hline R-CHOP & 12 & 6 & 0 & 18 \\
\hline Docetaxel + irinotican & 8 & 10 & 0 & 18 \\
\hline Gemcitabine + oxaliplatin & 10 & 6 & 0 & 16 \\
\hline Adriamycin + cyclophosphamide & 6 & 5 & 2 & 13 \\
\hline Paclitaxel & 3 & 9 & 0 & 12 \\
\hline Docetaxel + carboplatin & 4 & 5 & 2 & 11 \\
\hline Pemetrexed + carboplatin & 5 & 4 & 1 & 10 \\
\hline BEP & 5 & 5 & $\mathrm{O}$ & 10 \\
\hline Gemcitabine + capecitabine & 2 & 6 & 0 & 8 \\
\hline CAF & 6 & 2 & 0 & 8 \\
\hline Oxaliplatin + bevacizumab/ capecitabine & 4 & 4 & 0 & 8 \\
\hline Sunitinib & 5 & 3 & 0 & 8 \\
\hline Adriamycin + ifosfamide & 4 & 3 & 0 & 7 \\
\hline Pemetrexed + cisplatin & 1 & 5 & 0 & 6 \\
\hline Bevacizumab + capecitabine & 3 & 2 & 1 & 6 \\
\hline Paclitaxel + cisplatin + Ifosfamide & 5 & 1 & 0 & 6 \\
\hline Gemcitabine & 3 & 3 & 0 & 6 \\
\hline Docetaxel + cisplatin & 1 & 4 & 0 & 5 \\
\hline Cisplatin + capecitabine & 3 & 2 & 0 & 5 \\
\hline Trastuzumab & 3 & 2 & 0 & 5 \\
\hline Adriamycin + paclitaxel + trastuzumab & 3 & 2 & $\mathrm{O}$ & 5 \\
\hline Irinotican & 2 & 3 & 0 & 5 \\
\hline Docetaxel + cyclophosphamide & 1 & 3 & 0 & 4 \\
\hline Formorubicin + cyclophosphamide & 3 & 1 & 0 & 4 \\
\hline EC & 3 & 1 & 0 & 4 \\
\hline Vincristine + etoposide + carboplatin & 0 & 4 & 0 & 4 \\
\hline Docetaxel + doxorubicin + cyclophosphamide & 1 & 3 & 0 & 4 \\
\hline DCF & 2 & 2 & 0 & 4 \\
\hline Total & 380 & 442 & 18 & 840 \\
\hline
\end{tabular}


Most of the adverse drug reactions in the study population were in the age group of 40-50 years $(29.76 \%)$ followed by $50-60$ years $(28.92 \%)$. Adverse drug reactions were more common in males $(50.95 \%)$ as compared to female $(49.04 \%) .52 .6 \%$ of the adverse drug reactions were moderate in severity, $45.2 \%$ were mild and $2.14 \%$ were severe. Platinum group of drugs (Cisplatin, Carboplatin, Oxaliplatin) were responsible for most of the Adverse drug reactions followed by 5-FU and Taxanes (Paclitaxel and Docetaxel). ECF regimen caused $27.79 \%$ severe adverse drug reactions followed by $5-\mathrm{FU}+$ cisplatin.

\section{DISCUSSION}

Adverse drug reactions significantly diminish quality of life, increase hospitalizations, prolong hospital stay and increase mortality. ${ }^{10}$ The financial cost of Adverse drug reactions to health care system is enormous. ${ }^{10}$ The ADR prevalence encountered that practically all patients receiving cytotoxic drugs suffer one or more Adverse drug reactions. ${ }^{11,12}$ The present study was a prospective and observational study conducted by the department of pharmacology in collaboration with the department of radiation oncology and department of medicine between 1st April 2015 to October 2016 with the aim of finding out the frequency of adverse drug reactions among patients treated with anticancer drugs and to ascertain the causality and severity of these adverse drugs reactions. WHO-UMC scale was used for causality assessment and modified Hart Wig and Siegel scale was used to assess ADR severity. Out of a total of 141 patients, there were $76(53.9 \%)$ males and $65(46.1 \%)$ females. So, number of males was more than the number of females as is also found in the studies. ${ }^{12,13}$ The overall prevalence of Adverse drug reactions in this study was $100 \%$ i.e. all 141 enrolled patients developed one or more Adverse drug reactions during the follow up. This is in accordance with the study. ${ }^{11}$ Total number of 840 adverse drug reactions were noted in 141 patients and the average number of adverse drug reactions per patient was 5.95. Males were more affected by adverse drug reactions than females. Most of the adverse drug reactions were encountered in the age group of 40-50 years. The most common adverse drug reactions were loss of appetite $80.90 \%$, nausea vomiting $72.3 \%$ and alopecia $50.73 \%$. As per WHO - UMC scale $330(39.28 \%)$ were certain, 286 $(34.04 \%)$ were probable, $213(25.35 \%)$ were possible and $11(1.30 \%)$ were unlikely.According to Hart wig and Siegel scale for severity assessment out of 840 ADR's 442 $(52.06 \%)$ were moderate, $380(45.02 \%)$ were mild and 18 $(2.14 \%)$ were severe.Platinum group of drugs were responsible for most of the adverse drug reactions followed by 5 - Fluorouracil and Taxanes.

\section{CONCLUSION}

All antineoplastic drugs have potential to cause one or more adverse drug reactions, which may vary from mild to severe form as seen in the present study. These drugs have a narrow therapeutic index and the dosage needed to achieve a therapeutic response usually proves toxic to the body's rapidly proliferating cells. Measures need to be put into place to reduce the physical, emotional and economic burden on the patient due to adverse drug reactions. Therefore there is a need for vigilant ADR monitoring to decrease morbidity and mortality due to ADR's which require further studies on large populations. The yield could be better if monitoring is focused on individual drugs or formulations and the monitoring team includes a committed oncologist. Patient tolerance is an important factor and there is a high need for patient councelling about the therapy and possible ADR's during treatment.

Funding: No funding sources

Conflict of interest: None declared

Ethical approval: The study was approved by the Institutional Ethics Committee

\section{REFERENCES}

1. Wiffen P, Gill M, Edwards J, Moore A. Adverse drug reactions in hospital patients. A systematic review of prospective and retrospective studies. Bandolier Extra. 2002;2:1-16.

2. Lazarou J, Pomeranz BH, Corey PN. Incidence of adverse reactions in hospitalized patients - A metaanalysis of prospective studies. JAMA. 1998;279:1200-5.

3. Ali I, Wani WA, Saleem K. Cancer scenario in India with future perspectives. Cancer Therapy. 2011;8:5670.

4. Wynder, Ernst I, Lirio S. Covey, Kiyohikomabuchi. Current smoking habits by selected background variables: their effect on future disease trends. American Journal of Epidemiology. 1974;100.3:16877.

5. Chabner BA, Amrein PC, Bruken BJ. Antineoplastic agents. In: Bruntan LL, Lazo JS, Parker KL, editors. Goodman and Gillman's The Pharmacological Basis of Therapeutics. $11^{\text {th }}$ Ed. USA: McGraw Hill Companies. Inc.; 2006:1315.

6. Muller T. Typical medication errors in oncology: Analysis and prevention strategies. Onkologie. 2003;26:539-44.

7. Lau PM, Stewart K, Dooley M. The ten most common adverse drug reactions (ADRs) in oncology patients: do they matter to you? Support Care Cancer. 2004; 12:626-33.

8. WHO. International drug monitoring - the role of the national centers. Tech Rep ser WHO, No. 1972;498.

9. Hartwig SC, Seigel J, Schneider PJ. Preventibility and severity assessment in reporting adverse drug reactions. Am J Health Syst Pharm. 1992;49(9):222932.

10. Classen D, Ptestotnik SL, Scott Evans R. Adverse drug events in hospitalized patients: excess length of stay, extra costs and attributable motility. JAMA. 1997;277:301-06.

11. Kirthi C, Azra A, Reddy M, Syed AA, Yerramilli A, Sharma S. A study on the adverse effects of anticancer 
drugs in an oncology center of a tertiary care hospital. Int J Pharm Pharm Sci. 2014;6(2):580-3.

12. Goyal YN, Solanki KC, Mistry RA, Joshi ND, Singh AP, Gajera MV. Pattern of Adverse Drug Reactions Due to Cancer Chemotherapy in Tertiary Care Teaching Hospital in Gujarat. International Journal of Scientific Research. 2014;3(1):333-5.

13. Prasad A, Datta PP, Bhattacharya J, Pattanayak C, Chauhan AS, Panda P. Pattern of adverse drug reactions due to cancer chemotherapy in a tertiary care teaching hospital in Eastern India. J Pharmacovigilance. 2013 Feb 8;1(2):107.

Cite this article as: Rasool S, Nazeer M, Majeed M. Assessment of causality and severity of various reported adverse drug reactions by different classes of anti-cancer drugs. Int J Basic Clin Pharmacol 2018;7:503-10. 